\title{
VALIDITY OF LEARNING MATTER BASED ON A SCIENTIFIC APPROACH ON CHEMICAL EQUILIBRIUM MATERIAL
}

\author{
Nindi Sheliana Putri Yunita dan*Rudiana Agustini \\ Chemistry Department FMIPA State University of Surabaya \\ email: rudianaagustini@unesa.ac.id
}

\begin{abstract}
This study aims to produce a learning matter based on a scientific approach on chemical equilibrium material that is reviewed from the content validity and construct through the results of validation experts. This type of research is a 4-D research model (Define, Design, Develop, and Disseminate) but in this study limited on the development step. The validity results showed that: (1) The content validity obtained valid criteria with average percentage of $80 \%$. (2) The construct validity obtained highly valid criteria with average percentage of $88.7 \%$. From the results, it can be concluded the learning matter based on a scientific approach on chemical equilibrium material was declared valid, reviewed from the content, and construct validity by three validators.
\end{abstract}

Keywords:The Validity, Learning Matter based on a Scientific Approach, Chemical Equilibrium

\section{INTRODUCTION}

The 2013 curriculum is the curriculum currently used in Indonesia. The 2013 curriculum emphasizes the improvement and balance between student's soft and hard skills which include three aspects that are attitudes, skills, and knowledge [1]. The 2013 curriculum is applied to all the subjects from elementary to high school. One of the subjects taught at the high school level is chemistry.

Chemistry is one of the subjects in the science and technology group at the SMA/MA/SMALB level [2]. Chemistry itself has been taught to students at the SMP/MTs level include onto science subjects. Chemistry is a subject that studies the composition, structure, properties, and changes in energy that accompany changes in a matter [3]. The matter of chemistry emphasizes natural phenomena and their measurement by expanding on an abstract concept. Each matter has different characteristics, so this is what the teacher uses as a guide in determining the learning model to be used as well as any media that can support the learning process. Learning models or media that are not appropriate with the characteristics of the matter causes difficulty in student understanding. It causes the learning results obtained do not match what is expected.

Based on the interview result that has been conducted to one of the high school teachers of chemistry in Mojokerto on October 22, 2019, students had low scores on three matters, that are on the Element Periodical System, Redox, and Chemical equilibrium matter. The questionnaire was given to SMAN 1 Puri Mojokerto students to find out what is the most difficult matter of chemistry to learn. Based on the questionnaire result, chemical equilibrium matter is the most difficult matter.

Chemical equilibrium matter is the subject that is given to $11^{\text {th }}$-grade students in the second semester [4]. The chemical equilibrium matter consists of concept definition, abstract concepts, mathematical and graphical calculation [5]. Based on pre-research was getting $70.3 \%$ of the learning process is dominated by teacher explanation. The student's understanding can be increased by using one of the learning approaches. A Learning approach that makes the student actively participate actively in the learning process according to the 2013 curriculum is a scientific approach.

Learning using a scientific approach is learning designed by the teacher to build student's understanding which includes 5 elements namely observing, asking questions, gathering information, reasoning, making conclusions, and communicating [6]. Learning by using a scientific approach connects the concepts in theory with real life, so it can be motivated students to learn more through active learning [7]. Learning that participates students actively in the learning process caused the interaction between teacher-student and studentstudent can occur effectively [8]. This effective 
interaction can motivate students in the learning process.

Based on the results of the interview with the chemistry teacher, the learning process by using a scientific approach is not maximally applied because there still limited scientific-oriented learning matter. This is supported by the results of the student's questionnaire response, $71.8 \%$ of students stated if the learning matter that had been used only contained matter summaries, practice exercise, and student worksheets without encouraging students to discuss or find the concept by themselves. Based on the results of observations on the worksheets used in the chemistry learning process in high school, it was found that the worksheets that had been used only contained material summaries and then questions to measure the level of understanding of students. Chemical equilibrium material allows for experiments in the laboratory but the existing worksheets do not contain chemical equilibrium phenomena so that they do not stimulate students to carry out learning using scientific methods.

Learning matter is an important component of the learning process because learning matters include knowledge, skills, and attitudes that have to be learned by the students to achieve competence standard [9]. Learning matter based on a scientific approach is a learning matter that adopts the scientific method to build knowledge. The scientific method is a process of finding the truth through scientific stages. The scientific method used in the learning process can improve the soft and hard skills of students.

The first stage in the scientific method is to formulate problems obtained through the process of observation and interviews. In the interview process, the ability to communicate and reason students are sharpened so that students can find the root of the problem which will then be solved. The next stage is collecting information from relevant sources, at this stage, the ability of students to absorb information is sharpened so that a hypothesis can be formulated which is a temporary answer to existing problems. Furthermore, to prove the hypothesis, an experiment was carried out that hone the motor skills of students in using laboratory tools. The results of the experiment were then analyzed so that a conclusion was obtained which was then communicated which hone the soft skills of students. Because of the complete benefits obtained in learning that applies scientific methods, it is important to implement scientific approachbased learning because it is in accordance with the objectives of implementing the 2013 curriculum. Based on the results of research learning matter based on a scientific approach to physics subjects got a positive response from students [10].

Based on that description, this study aims to produce a learning matter based on a scientific approach to chemical equilibrium material that is reviewed from the content validity and construct through the results of validation experts.

\section{METHOD}

This study is development type research with a 4-D development design. The 4-D development design consists of 4 stages: define, design, develop, and disseminate [11]. This study is limited to the stage of development. The target of this study is learning matter based on a scientific approach to chemical equilibrium material.

The instruments used in this study were the review sheet and the validation sheet. The review sheet is filled in by the lecturer to get suggestions before it is validated by the validator. The validation sheet is filled in by three validators consist of two chemistry lecturers and one chemistry teacher. This validation sheet used to measure the content and construct validity. The validation sheet is filled in based on a Likert scale with the following evaluation criteria:

Table 1. Likert Scale of Validity

\begin{tabular}{cc}
\hline Assesment & Score \\
\hline Very Less & 1 \\
Less & 2 \\
Enough & 3 \\
Good & 4 \\
Very Good & 5 \\
\hline
\end{tabular}

The percentage of learning matter validity was calculated using the following formula:

Percentage $=\frac{\text { Eeach aspect score }}{\text { Lcriterion score }} \times 100 \%$ 
Criterion score $=$ maximal score on each aspect $\mathrm{x}$ number of validator.

The percentage of learning matter validity was interpreted using the following criteria:

Table 2. Criteria of Learning Matter Validity Interpretation

\begin{tabular}{cc}
\hline Percentage (\%) & Category \\
\hline $0-20$ & Not valid \\
$21-40$ & Less valid \\
$41-60$ & Valid Enough \\
$61-80$ & Valid \\
$81-100$ & Very Valid \\
\hline
\end{tabular}

The learning matter is categorized valid if each content and construct validity have a percentage $\geq$ of $61 \%$.

\section{RESULT AND DISCUSSION}

The results and discussion of research data based on 4-D development design are described as follows.

\section{Define Stage}

The aims of the define stage are to determine and define the needs of study. The define stage consists of 5 steps namely front end analysis, student analysis, task analysis, concept analysis, and formulation of learning objectives. The front end analysis aims to find out the problems in chemistry learning. Front-end analysis is obtained based on the results of observations, interviews, and questionnaires. This analysis refers to the curriculum used in school. The curriculum used at SMAN 1 PuriMojokerto is the 2013 curriculum. Based on the results of the analysis, students have difficulty understanding chemical equilibrium material. Chemical equilibrium material taught to students in grade 11 in the second semester, namely in Basic Competence 3.9 and Basic Competence 4.9 [4].

Analysis of students is done by observing the characteristics of students which include the ability and experience of students as individuals and groups, age, and student's motivation in learning chemistry. The subject of this study is students on average age 17 years. At this age, children are at the formal operational stage, on this stage children can think abstractly with the use of hypotheses and logical reasons [13].

The chemistry learning experience of students is largely through the teacher's explanation. The students dominantly said the easiest study method to understand chemistry subject is by making a summary and practice the matter of chemistry directly.

Task analysis is used to define the tasks that will be given to students so the learning objectives can be achieved. The student tasks are to use learning matter in the learning process and then conduct experiments following the worksheet contained in learning matter.

Concept analysis aims to determine the contents of the material be examined. This analysis is made in a concept map so that learning material can be arranged systematically. The following is the concept map of chemical equilibrium material.

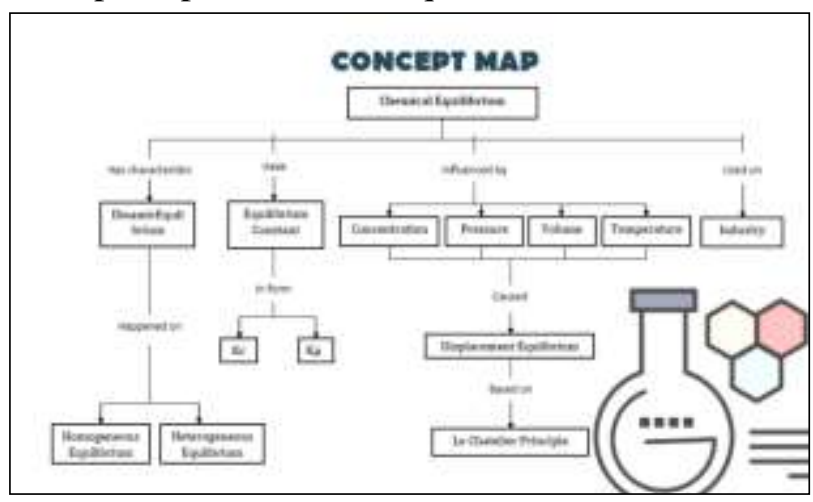

Figure 1. Concept Map of Chemical Equilibrium Material

The formulation of learning objectives is based on tasks and concepts analysis that has been done before.

\section{Design Stage}

At this stage developed learning matter is designed.The learning matter consists of 4 learning materials and worksheets on chemical equilibrium material. The learning matter is arranged according to the student's needs. The amount of matter presented in the learning matter depends on the basic competencies to be achieved [14]. Learning based on a scientific approach supported by worksheet can improve student's learning outcomes [15] [16]. The use of worksheet can improve cognitively and psychomotor learning outcomes of students [17]. The resources of learning matter are 
printed and non-printed grade 11 chemistry books that are appropriate with the 2013 curriculum, and other learning resources that are relevant to chemical equilibrium materials. The developed learning matter is bilingual, using English and Indonesian language. Layout designs, drawings, and writing used are simply and appropriately adjusted to the student's age so easily to be read by students. At this stage, the learning matter called the initial design of learning matter. The following is the cover design of developed learning matter.

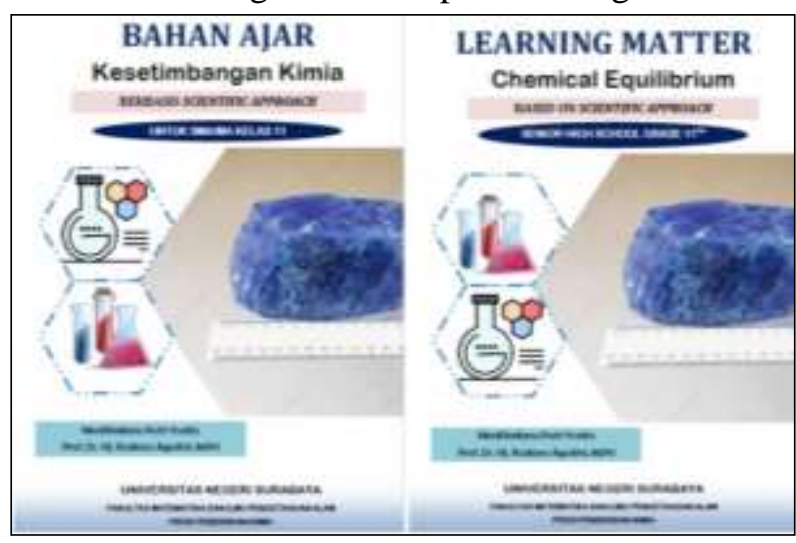

Figure 2. Cover Design of Learning Matter in Two Languages (Indonesian and English)

\section{Develop Stage}

The development stage aims to produce a learning matter that is ready to be used. This stage consists of two steps, namely a review of the learning matter and validity of learning matter.

a. The Review of Learning Matter

The initial design of the learning matter was reviewed by the chemistry lecturer. The results of the review are input and suggestions from the lecturer to improve the developed learning matter. The result of learning matter review are presented in the table below.

Table 3. Result of Learning Matter Review

\begin{tabular}{|l|l|}
\hline Initial Design & After Revised \\
\hline $\begin{array}{c}\text { Illustrations } \\
\text { description is unclear }\end{array}$ & $\begin{array}{l}\text { Illustrations are } \\
\text { accompanied by }\end{array}$ \\
\hline
\end{tabular}

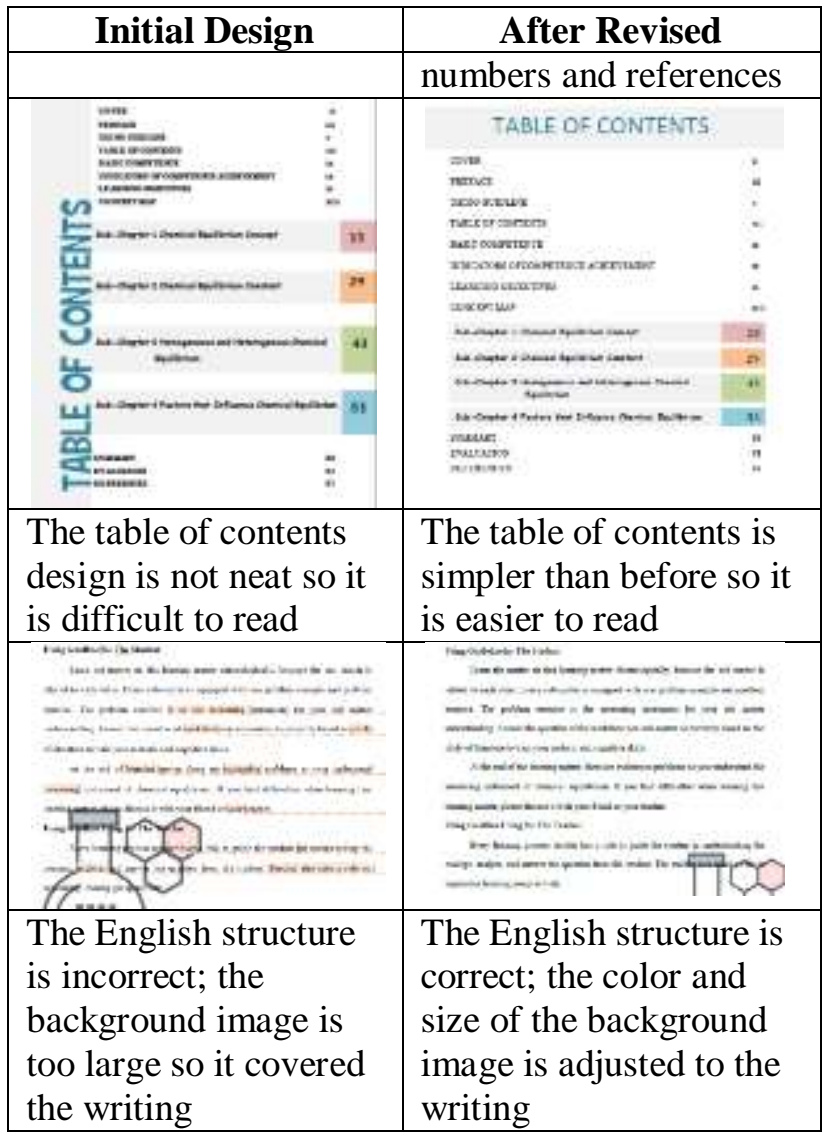

The initial design of learning matter that has revised based on review results are referred as draft I.

b. The Validity of Learning Matter

The learning matter referred to as a draft I is measured the validity by the validator. The validator consists of two expert lecturers and one chemistry teacher. The validity of learning matter is measured from the analysis result of content and construct validity [18]. The content validity shows the product is in accordance with the curriculum and has strong theoretical rationales. The percentage of content validity results are presented in table 4.

Table 4. Content Validity Results

\begin{tabular}{clcc}
\hline No. & \multicolumn{1}{c}{ Aspect Acessed } & $\mathbf{P}(\%)$ & Category \\
\hline 1 & $\begin{array}{l}\text { The compatibility of } \\
\text { Basic Competence } \\
\text { and indicators with } \\
\text { the } 2013 \text { curriculum }\end{array}$ & 86.7 & $\begin{array}{c}\text { Very } \\
\text { Valid }\end{array}$ \\
2. & $\begin{array}{l}\text { The suitability of } \\
\text { chemical equilibrium } \\
\text { material with the } \\
\text { indicators and }\end{array}$ & 86.7 & $\begin{array}{c}\text { Very } \\
\text { Valid }\end{array}$ \\
$\begin{array}{l}\text { learning objectives } \\
\text { The suitability of the }\end{array}$ & 73.3 & Valid \\
\hline
\end{tabular}




\begin{tabular}{llcc}
\hline No. & \multicolumn{1}{c}{ Aspect Acessed } & $\mathbf{P}(\%)$ & Category \\
\hline & $\begin{array}{l}\text { questions in learning } \\
\text { matter with } \\
\text { indicators and }\end{array}$ & & \\
$\begin{array}{l}\text { learning objectives } \\
\text { The suitability of } \\
\text { learning matter with } \\
\text { scientific approach }\end{array}$ & 73.3 & Valid \\
& & \\
activities & & \\
\hline Content validity average & 80 & Valid \\
\hline
\end{tabular}

The content validity average of developed

learning matter is $80 \%$. Content validity consists of four assessment aspects. First, the compatibility of basic competencies and indicators with the 2013 curriculum. This aspect obtains a percentage of $86.7 \%$ and gets a very valid category. This shows that the chemical equilibrium material in developed learning matter is appropriate with [4] which states that chemical equilibrium material is one of material in chemistry subject taught to students in grade 11 in the second semester.

The second aspect is the suitability of the chemical equilibrium material with the indicators and learning objectives. This aspect gets a percentage of $86.7 \%$ which categorized as very valid. This shows the material is appropriate with the basic competencies and learning objectives. The developed chemical equilibrium material is on basic competence 3.9, which is analyzing factors that influence equilibrium shift direction that is applied in industry and Basic Competence 4.9 namely designing, doing, concluding, and presenting the experiment result of the factors that influence the direction of equilibrium shift.

The third aspect is the suitability of the questions in learning matter with the indicators and learning objectives. This aspect is categorized valid because it gets a percentage of $73.3 \%$. The basic competencies of chemical equilibrium material are described in the learning indicators. These learning indicators are used in arranging the grid. This grid is used as guidance in compiling the questions that appropriate with the learning objectives [19].

The last aspect is the suitability of learning matter with scientific approach activities. This aspect gains a percentage of $73.3 \%$ with a valid category. This shows the developed learning matter has contained five learning activities that use a scientific approach. These five activities are observing, asking questions, gathering information, associating, and communicating [14].

In the observing process, students observe the phenomena presented in the learning matter so that students can ask about the problems that exist in the phenomenon. Furthermore, students collect information from learning matter or other relevant sources to formulate hypotheses. The hypothesis is then proven by experimenting. The results of the experiment were analyzed and then communicated.

The construct validity consists of three assessments aspect, namely language, presentation, and graphic. The percentage of each aspect is presented in table 5.

Table 5. Percentage of Construct Validity Result

\begin{tabular}{clcc}
\hline No. & $\begin{array}{c}\text { Aspects } \\
\text { Accessed }\end{array}$ & $\mathbf{P}(\%)$ & Category \\
\hline 1 & Language & 86.7 & Very Valid \\
2. & Presentation & 91.4 & Very Valid \\
3. & Graphic & 88 & Very Valid \\
\hline $\begin{array}{l}\text { Construct validity } \\
\text { average }\end{array}$ & 88.7 & Very Valid \\
\hline
\end{tabular}

The construct validity has an average percentage of $88.7 \%$, so it is categorized as very valid. The language aspect gets a percentage of $86.7 \%$ which is categorized as very valid. These results indicate that the language used is appropriate with Indonesian Language Rules. The sentences used are effective and efficient so that readers easily understand the contents of the learning matter. Indonesian language that simple and easy to understand can improve student's thinking abilities [20].

The second aspect is the presentation of learning matter. This aspect includes the material is presented sequentially so the learning becomes directed appropriately with learning objectives. The presentation aspect gains a percentage of $91.4 \%$ which is categorized as very valid. This high percentage of presentation aspect shows the picture presented in the learning matter is appropriate with the material, so the learning matter is interesting and fun to be used on the learning process. Illustrations in the textbook are important because it can increase the imagination so it can increase student creativity [21]. 
The third is the graphic aspect. The graphic aspect gets a percentage of $88 \%$ which is categorized as very valid. Assessment components of the graphical aspect include the cover, type, and size of font, layout, illustration, and display design [9]. The cover used on learning matter is interesting and presenting the content of learning matter. The cover of a book should be made as attractive and creative as possible because the more creative the design, the higher the student reading interest [21]. Reading interest has a positive influence on improving student learning outcomes [22]. The type of font used in the learning matter is Cambria with size 12. The type and the size of font are consistently used in learning matter so it is easy to read. The content and position of illustrations are appropriate with the chemical equilibrium matter. Besides the illustrations are presented clearly so its easily observed by students.

\section{CLOSING}

\section{Conclusion}

Based on the result and discussion it can be concluded the developed learning matter based on a scientific approach on chemical equilibrium matter is declared valid, reviewed from the content, and construct validity by three validators.

\section{Suggestion}

This study is conducted only to determine the validity of learning matter based on a scientific approach on chemical equilibrium matter so the next study can be conducted to measure the effectiveness and practicality of developed learning matter. It aims to determine the suitability of the developed learning matter.

\section{REFERENCES}

1. Asri, M. 2017. Dinamika Kurikulum Indonesia. MODELLING: Jurnal Program Studi PGMI, vol. 4, no. 2, pp. 192-202.

2. Permendiknas. 2006. Permendiknas No. 22 Tahun 2006 tentang Standar Isi untuk Satuan Pendidikan Dasar dan Menengah: Jakarta: Menteri Pendidikan Nasional.

3. Rosa, N. M. 2012. Pengaruh Sikap Pada Mata Pelajaran Kimia dan Konsep Diri Terhadap
Prestasi Belajar Kimia. Formatif: Jurnal Ilmiah Pendidikan MIPA, vol. 2, no. 3, pp. 218-226.

4. Permendikbud. 2016. Permendikbud No. 22 Tahun 2016 tentang Standar Proses Pendidikan Dasar dan Menengah. Jakarta: Kementerian Pendidikan dan Kebudayaan.

5. Satriana, T., Yamtinah, S., Ashadi, \&Indriyanti, N Y. 2018. Student's Profile of Misconception in Chemical Equilibrium. Journal of Physics: Conference Series, pp. 18.

6. Permendikbud. 2013. Permendikbud No. 81A Tahun 2013 tentang Implementasi Kurikulum. Jakarta: Kementerian Pendidikan dan Kebudayaan.

7. Arlianty, Widinda Normalia., Febriana, B.W., \&Diniaty, A. 2017. An Analysis of Learning Process Based on Scientific Approach in Physical Chemistry Experiment. AIP Conference Proceedings, pp. 1-7.

8. Saputri, Arnita Cahya. 2018. The Relationship between Scientific Approach and Science Teacher Interpersonal Interaction with Student Learning Outcomes in Junior High School. International Journal of Multicultural and Multireligious Understanding, vol. 5, no. 2, pp. 199-208.

9. Depdiknas. 2008. Panduan Pengembangan Bahan Ajar. Jakarta: Depdiknas.

10. Kartikasari, Henry Ayu.,Wahyuni, Sri., \&Yushardi. 2015. Pengembangan Bahan Ajar Berbasis Scientific Approach Pokok Bahasan Besaran dan Satuan di SMA. Jurnal Pendidikan Fisika, vol. 4, no. 1, pp. 64-68.

11. Ibrahim, M., \& Wahyusukartiningsih. 2014. Model Pembelajaran Inovatif Melalui Pemaknaan. Surabaya: Unesa University Press.

12. Riduwan. 2016. Skala Pengukuran dan Variabel-Variabel Penelitian. Bandung: Alfabeta.

13. Slavin, R. E. 2012. Educational Psychology Theory and Practice Tenth Edition. New Jersey: Prentice Hall.

14. Musfiqon.,\& Nurdyansyah. 2015. Pendekatan Pembelajaran Saintifik. Sidoarjo: Nizamia Learning Center. 
15. Diani, Rahma. 2016. Pengaruh Pendekatan Saintifik Berbantukan LKS Terhadap Hasil Belajar Fisika Peserta Didik Kelas XI SMA Perintis 1 Bandar Lampung. Jurnal Ilmiah Pendidikan Fisika, vol. 5, no. 1, pp. 83-93.

16. Mustika, Saptaningrum, Ernawati., \& Susilawati. 2016. Pengaruh Penggunaan LKS dengan Pendekatan Saintifik pada Materi Objek IPA dan Pengamatannya terhadap Hasil Belajar IPA Kelas VII MTs Negeri 1 Semarang. Jurnal Penelitian Pembelajaran Fisika, vol. 7, no. 1, pp. 63-71.

17. Aprilianti, Harmita., Rahayu, Enni Suwarsi.,\& Indriyanti, Dyah Rini. 2019. Development of Saintific-based Student's Worksheet (LKS) by Utilizing the Ferns Taxonomy Garden as a Supplementary of Plantae Teaching Material. Journal of Innovative Science Education, vol. 8, no. 2, pp. 221-227.

18. Nieveen, N., \&Folmer, E. 2013. Educational Design Research. Enschede: Netherlands Institute for Curriculum Development.
19. Susiatin. 2019. Meningkatkan Kemampuan Guru Dalam Menyusun Kisi-Kisi Soal dengan Metode Pendampingan Pola "OCF". Jurnal Dinamika Manajemen Pendidikan, vol. 4, no. 1, pp. 17-24.

20. Ellizar, E., Hardeli, H., Beltris, S., \& Suharni, R. 2018. Development of Scientific Approach Based on Discovery Learning Module. IOP Conference Series: Materials Science and Engineering, pp. 1-7.

21. Kasmaienezhadfard, Sara., Pourrajab, M., \& Rabbani, M. 2015. Effect of Pictures in Textbooks on Students's Creativity. Multi Disciplinary Edu Global Quest, vol. 4, no. 2, pp. 83-96.

22. Muslim. AR., Suyono, \& Nurchasanah. 2017. Pengaruh Minat Baca Terhadap Prestasi Belajar Siswa Sekolah Dasar. Prosiding TEP \& PDs, vol. 1, no. 10, pp. 56-63. 